\title{
Organizational Communication Model In Regional Government Of Sidoarjo District In Making Perda
}

\author{
Nova Retnowati \\ Faculty of Economics and Business, \\ Bhayangkara Surabaya University, \\ Djoko Sumaryanto \\ Faculty of Law, \\ Bhayangkara Surabaya University \\ Rini Ganefwati \\ Faculty of Social and Political Sciences, \\ Bhayangkara Surabaya University
}

\begin{abstract}
ABSRACT
The main key to the implementation of Regional Government (Pemda) in the making of local regulations (Perda) is the well-established organizational communication among the management of the management, so that it can equalize perceptions to support and accelerate development programs in the region. With harmonious organizational communication can be avoided slow process, long-winded, so that it is not efficient which results in the direction of regional development to be inconsistent (Sadu Wasistiono, 2010: 42). For this reason, local government managers should have a partnership and equal relationship. This partnership relationship is important in the process of making a Perda. This study uses a qualitative approach that is focused on identifying the dominant factors that can facilitate the communication of local government organizations in the process of making Perda. Data collection techniques use purposive methods and domain analysis. Thus, this research is expected to be studied in a normative, sociological manner that is comprehensive and holistic. This study resulted in the finding of 4 (four) dominant factors in organizational communication in the Sidoarjo Regency Government which became a catalyst in the implementation of local democracy, namely facilities, budget support, staff competence, and good relations with mass media. Through classifying the flow of communication based on the domain that has been established, the research team can finally build a communication model of the Sidoarjo Regency Government organization in the process of making the Perda.
\end{abstract}

Key words: Organizational Communication, District Government, Regional Regulation.

\section{INTRODUCTION}

The realization of local democracy is evident since the enactment of direct regional elections (Pilkada) and direct legislative elections (Pileg) in 2005. The current regional government organization refers to the Attachment to Law Number 1 of 2015 concerning the stipulation of Law Number 1 of 2014, in Article 1 paragraph 22 stated that the Regional Government (Pemda) is the organizer of Government affairs by the Regional Government and the Regional People's Legislative Assembly (DPRD ) according to the principle of autonomy and coadministration with the principle of the Republic of Indonesia. So the provincial government organizer is the Governor with the provincial DPRD and the organizer of the City / Regency Government is the Mayor / Regent with the City / District DPRD (Article 3 of Law No. 32 of 
2004). In a state administration perspective, the position of Regional Head and DPRD is parallel, meaning that both regional institutions have partnership relations.

With the direct election system, it gives consequences that the DPRD can no longer bring down the Regional Head before his term ends through a political decision, but must first go through a legal process in court (Rozali Abdullah, 2011: 4). This partnership relationship is important in the process of making a local regulation. The Regional Head is an executive institution which in empirical reality is more dominant in public policy making while the DPRD is a legislative institution that is more dominant in its determination process.

Current phenomena in Indonesia indicate that the creation of a regional regulation can come from executive initiations (regents and staff) and legislative initiation (DPRD). In this process it often happens to be protracted and loaded with political interests. Decision making becomes slow, long-winded, so it is not efficient, as a result the direction of regional development becomes inconsistent because it is loaded with the interests of the dominant party (Sadu Wasistiono, 2010: 42). In the Banyuwangi regional election conflict, the DPRD made recommendations to the Governor and the Minister of Home Affairs to remove the elected Regent (Irtanto, 2008: 42). This fact is a confusion about the role of the DPRD in the elections. The implementation of the election is indeed the authority of the Election Commission, but its accountability must be submitted to the DPRD, so that it has the potential to be intervened by the power of the dominant party in the DPRD.

Another empirical reality that often arises is a corruption case involving the budget line in the APBD. Recorded extortion of several Regional Heads who carry out annual accountability reports and final position accountability reports and in the process of selecting candidates for regional heads (B.N.Marbun, 2005: 148). The principle of decentralization should be able to reduce potential conflicts of interest and build harmonization within the regional government. The main key in implementing a harmonious Local Government is "healthy" organizational communication that can equalize the perception of local government and DPRD management officials to prioritize the public interest and release group interests, so that the process of making local regulations can run effectively and efficiently which leads to optimal development in the region. The model of communication of this Regional Government organization must be designed to be a legal norm so that there is a juridical basis for its implementation.

From the above phenomenon, the research team intends to create a model of communication of the Local Government organization in realizing the good practices of local democracy through the process of making Perda by first exploring the existence of dominant factors in organizational communication in the Sidoarjo Regency government. 


\section{METHODS AND MATERIALS}

Table 1. Methods and stages of research

\begin{tabular}{|c|c|c|c|}
\hline No & Research methods & \multicolumn{2}{|c|}{ Stages of Research } \\
\hline 1. & Approach & \multicolumn{2}{|c|}{$\begin{array}{l}\text { This research is an explorative research that is technically applicable } \\
\text { with a multidisciplinary approach, namely the approach of } \\
\text { Organizational Communication, Local Government Governance, and } \\
\text { Regional Regulations. }\end{array}$} \\
\hline 2. & Location & \multicolumn{2}{|c|}{ In Sidoarjo Regency (Executive and Legislative Institutions) } \\
\hline 3. & Analysis Unit & \multicolumn{2}{|c|}{$\begin{array}{l}\text { Determination of the unit of analysis in this study using purposive } \\
\text { sampling technique. The researcher explores and determines key } \\
\text { figures related to research problems, namely the Regent / staff and } \\
\text { the Sidoarjo Regency DPRD. }\end{array}$} \\
\hline 4. & Data collection technique & \multicolumn{2}{|c|}{$\begin{array}{l}\text { Data collection was carried out by in-depth interviews with key } \\
\text { figures who became the unit of analysis to obtain primary data, and } \\
\text { observations to obtain secondary data }\end{array}$} \\
\hline \multirow[t]{3}{*}{5.} & Data Analysis Techniques & \multicolumn{2}{|c|}{$\begin{array}{l}\text { This study uses domain analysis, namely by making categorization } \\
\text { based on the context of the communication of the Pemda organizing } \\
\text { organization (Spradly in Sugiyono, 2005: 103) as follows: }\end{array}$} \\
\hline & & DOMAIN & KATEGORISASI \\
\hline & & $\begin{array}{ll}1 . & \text { Executive Institution } \\
2 . & \text { Legislative Institution } \\
3 . & \text { Regional Policy } \\
\end{array}$ & $\begin{array}{l}\text { Regent / staff } \\
\text { District DPRD } \\
\text { Making Regional Regulations }\end{array}$ \\
\hline
\end{tabular}

\section{THEORETICAL FRAMEWORK}

\section{Organizational Communication}

Understanding organizational communication in the book "organizational communication strategy to improve company performance" is the organizational behavior that occurs and how those involved in the process transact and give meaning to what is happening (R.Wayne Pace \& Don F. Faules, 2006: 33). Golddhaber (1986) provides a definition of organizational communication as a process of creating and exchanging messages in a network of interdependent relationships to overcome uncertain or ever-changing environments.

From the definition put forward by experts regarding organizational communication it can be concluded that the definition of organizational communication is:

1) Communication that occurs in an open system that is influenced by internal and external parties

2) Communication which includes messages, goals, communication flows and communication media

3) Communication that includes people who have the same skills, relationships and feelings.

There are 2 (two) types of message flows in organizational communication namely vertical communication and horizontal communication.

\section{Vertical communication}

Vertical communication is divided into 2 directions, namely downward communication and upward communication. 


\section{Downward communication}

The communication process that goes from a certain level in a group or organization to a lower level is called downward communication. For example managers communicate with their subordinates. The pattern is used by leaders to achieve its objectives, such as: giving work instructions, informing a regulation and procedures that apply to his subordinates, determining problems that need attention. Communication in this form does not have to be verbal or face to face, memos or letters sent by directors to subordinates also include downward communication (Stephen P Robbins, 1999: 148).

In many organizations, downward communication is often insufficient and inaccurate. Subordinate complaints indicate ineffective communication. Subordinates need information relevant to their work (John M. Ivancevich, Robert Konopaske, Michael T. Matteson, 2006: 121). Information from superiors to subordinates includes (Yulius Eka Agung Saputra, 2014: 172):

1) Information about how to do work.

2) Information about the rationale for doing the work.

3) Information about organizational policies and practices.

4) Information about employee performance.

5) Information to develop a sense of belonging.

\section{Upward communication}

Understanding of communication and above is the activity of subordinates to convey information, ideas, opinions, and other statements to the leadership with the intention of influencing the behavior and policies of the leader. Gary Kreps, a researcher in the field of organizational communication, found several communication functions upward among them (John M. Ivancevich, op.cit: 121):

1) Providing feedback for managers on the latest organizational issues, problems encountered, and information about operations day by day needed for decision making about how to run the organization.

2) It is the main source for management to get feedback to determine how effective communication is down in the organization.

3) Can reduce tension on employees by providing opportunities for members of the organization at a lower level to distribute information relevant to their superiors.

4) Encourage employee participation and involvement, so as to increase organizational cohesiveness.

\section{Horizontal communication}

The definition of horizontal or horizontal communication is the exchange of messages between people of the same level of authority in the organization (Muh. Arni, 2007: 121). When communication occurs between members of the same working group, or fellow staff members who are equal are called lateral / horizontal communication. Why is horizontal communication needed if vertical communication in groups is still effective? the answer is that horizontal communication can save time and can facilitate coordination. In some cases, horizontal communication can be formally justified. Often horizontal communication is informally made to cut vertical lines of authority and can speed up decision making (Stephen P. Robbins, op. Cit: 149).

\section{Pemda}

Is the administration of government affairs by the Regional Office and the DPRD according to the principle of autonomy and the task of assistance with the principle of autonomy to the greatest possible extent in the system and principles of the Unitary State of the Republic of 
Indonesia as referred to in the 1945 Constitution (Article 1 paragraph 2 of Law No. 32 of 2004). The local government in this study is the Regent / staff and the Regency DPRD.

\section{Local Democracy}

Local democracy is part of the political subsystem of a country whose degree of influence is within the local government corridor. In Indonesia, local democracy is a subsystem of democracy which provides opportunities for local governments to develop relations with the people in their region (Deden Faturohman, 2005: 45). Local democracy is also understood as a way of democratizing (governing) in:

1. Local government institutions in this study are Bupati, DPRD, committees, and administrative services

2. In organizing and community activities.

The values that underlie democracy according to Miriam Budiardjo, (2008: 105) are: a) institutionalized peaceful settlement of conflict, b) peaceful change in a changing society, c) orderly succession of rulers, d) minimum of coercion, e) diversity, f) guarantee the upholding of justice.

\section{Perda}

Is a series of actions carried out by the Regional Government that are oriented to solving public problems or in the public interest, or Regional Regulations are made with the aim of regulating everything related to the wheels of government and community life in the region. The regional policy in this study is the Regional Regulation (Regents / Regulations). Perbup was made by the Regent, which was carried out after obtaining approval from the Regency DPRD.

\section{RESULTS}

In this study, local democracy is understood as a way of democratizing (governing) in the Sidoarjo regency, which is related to the process of making a law, which involves the executive and legislative.

One important aspect in the implementation of local democracy in this study focuses more on the management of organizational communication which describes the flow of messages based on the authority and power attached to the two parties involved in the process of making local regulations. As for the unit of analysis in this study are key figures from the executive are represented by: the Office of Communication and Information, Legal Section, Regional Secretariat, and the legislative (DPRD) of Sidoarjo Regency. Based on the results of interviews with key figures, information was obtained about the answers to the research problems explored by the research team as follows:

\section{The dominant factor that triggered good practices in organizational communication in Sidoarjo Regency Government}

Assessing organizational communication in the process of making local regulations in Sidoarjo Regency is done by observing the implementation of the roles carried out by officials in their capacity as local elites who exchange messages. That the drafting and drafting of the Regional Regulation must refer to the relevant laws and regulations. Besides that, it is also necessary to know the real conditions in the field.

To find out the actual conditions, the agenda of the public consultation activities with stakeholders and the community was made directly related to the material of the draft Regional Regulation to be drafted. Information extraction is carried out through both print and electronic media. The Information and Documentation Management Officer (PPID) is an official 
who is responsible for the storage, documentation, provision and service of information in the public body.

\section{Authority of PPID}

- Coordinate each unit / work unit in the Public Agency in carrying out Public Information services.

- Deciding a Public Information can be accessed publicly or not based on testing of consequences.

- Refusing requests for public information in writing if the requested public information includes excluded / confidential information accompanied by reasons and notices about the rights and procedures for the applicant to file an objection to the refusal.

- Assign functional officials and information officers under their authority and coordination to make, maintain, and update the list of public information on a regular basis at least 1 time a month.

\section{PPID Duties and Responsibilities:}

1. Provision, storage, documentation and information security

2. Information services in accordance with applicable rules

3. Fast, precise and simple Public Information Services

4. Determination of operational procedures for the dissemination of Public Information

5. Consequences Testing

6. Classification of information and changes

7. Determination of Exempt Information which has expired Exemption Period as Public Information that can be accessed

8. Determination of written consideration for every policy taken to fulfill everyone's right to Public Information

In this study the research team has set a sample in the making of the People's Market Regulation. The process of making a local regulation begins with a draft regional regulation involving officials related to the management and empowerment of the people's market in the Sidoarjo Regency. Through the Regional Regulation, it is expected that it can improve the competitiveness of the people's market, improve access to buying and selling transactions comfortably and the welfare of traders. In addition to the smooth logistics and distribution of material needs and encourage the strengthening of the domestic market in the era of global competition. Authority related to the people's market has been regulated in Article 14 paragraph 1 of Law number 7 of 2017 concerning trade.

The article states that Sidoarjo regency government is in accordance with its authority to regulate the development, structuring and coaching that is equal and equitable towards the people's market. Also discussed about the arrangement, licensing, spatial planning, zoning with regard to distance and location of establishment, partnership and business cooperation.

On the other secondary data as a sample of the Regional Regulation that has been selected and successfully collected and analyzed, the research team is the District Head Regulation (Perbup) socialization activity No. 3 of 2018 on the division of authority, duties and functions in the implementation of disaster management in Sidoarjo Regency which has been held in the Delta Karya room 2nd floor Secretariat of the district of Sidoarjo regency on Thursday 26 April 2018. This is deemed necessary considering that Sidoarjo Regency was once hit by a National disaster, namely the "Lapindo mudflow" which until now has still been completed thoroughly and thoroughly. Disaster management must be carried out quickly, precisely, directed and integrated by involving all stakeholders consisting of 3 (three) pillars, namely: local 
government, business world, and the community which in its implementation must refer to the applicable provisions.

For this reason, Perbup Sidoarjo is needed so that each skateholder can know its authority, duties and functions so that when a disaster occurs it is ready to carry out the handling of the route quickly, accurately, directed and integrated, so socialization activities are needed. The event was opened by the Secretary of Sidoarjo Regency, Drs. Achmad Zaini (Regional Secretary of Sidoarjo Regency) and was attended by Chairman of the Commission D of the Sidoarjo DPRD, the ranks of the regional leadership Communication Forum, Kabag. Law, BPBD and SKPD throughout Sidoarjo Regency.

From the results of interviews and filling out questionnaires submitted by the research team at the Sidoarjo Regency Office of Communication and Information, data was obtained that organizational communication that took place in the process of making regional regulations was carried out through the creation of online applications, data exchange between each Regional Device Organization (OPD), media center, collaboration with Press, and Community involvement. The organizational communication pattern aims to open space for the public to be known:

$>$ various information,

$>$ provides development information, as well as

$>$ provide the latest information through electronic media and print media.

The task carried out by the Ministry of Communication and Information is to communicate and inform the public about the policies in the local government. This is in line with the function of the Sidoarjo Regency Communication and Information Section, in addition to carrying out its function as a communication organizer, it also acts as the manager of public aspirations and reactions or public opinion.

\section{DISCUSSION AND CONCLUSION}

The dominant factor that triggers good practices in organizational communication in Sidoarjo Regency are:

$>$ Facilities for office facilities are quite complete,

$>$ budget support as the implementation of the Kominfo work system has been prepared to accommodate,

$>$ Staff who have the ability in accordance with their fields, and

$>$ relations with the mass media are well established.

In addition, it is also necessary to avoid the obstacles that are often encountered in the implementation of the tasks of the Ministry of Communication and Information, namely:

$>$ the bureaucracy is still hesitant to provide information to the public afraid of becoming viral,

$>$ sometimes the applicant for information is not purely asking for information / has an agenda or other purpose

$>$ the mindset of the people who are still unfamiliar about each local government policy and

$>$ culture that is still traditional which is binding on material culture.

\section{Sidoarjo regency government organization communication model in the process of making local regulations.}

The regional regulation in this study is the Regional Regulation of Sidoarjo Regency which was formed and or stipulated by the Regency DPRD with the joint approval of the Regent. District 
regulations are not subordinate to provincial regulations. Planning the drafting of Regional Regulations as stipulated in article 15 paragraph 2 of Law No.10 of 2004 concerning the Formation of Legislation mentioned that "the drafting of regional regulations is carried out in a regional legislation program (Prolegda)".

The draft Regional Regulation (Raperda) can come from the DPRD or regional head (Bupati). The Raperda by the Regent was submitted to the DPRD. While the Raperda by the DPRD was conveyed by the DPRD leaders to the Bupati. Discussion of the Raperda in the DPRD is carried out by the DPRD with the Regent. The discussion is carried out through 2 (two) levels of communication, namely: level 1. In the Commission / committee / Balegda in the committee meeting / committee / completeness of the DPRD that specifically handles legislation; level 2. Endorsement at the plenary meeting.

The Raperda that was jointly approved by the DPRD and the Regent was conveyed by the Head of the Regency DPRD to the Regent to be ratified as a Perda, within a period of no later than 7 days from the date of mutual agreement. The Raperda was ratified by the Regent by signing within 30 days of the Raperda being approved by the DPRD and the Bupati. If within 30 days of the Raperda being mutually agreed upon it is not signed by the Regent, the Raperda is declared valid to become a Perda.

The content of the Perda is in the form of policy material that is made in the context of the implementation of regional autonomy and assistance tasks that accommodate the special conditions of the region and further elaboration of the higher legislation. There are 3 (three) stages in the drafting process of the Perda, namely:

a) the drafting process for the Raperda (can be from executive / regent initiatives or from legislative / DPRD initiatives,

b) the process of obtaining approval in discussions at the DPRD and

c) the process of ratification by the Regional Head and enactment by the Regional Secretary.

Briefly the discussion of the Regional Regulation is summarized in table 2 below: 
Table 2. Organizational Communication in Making Perda

\begin{tabular}{|c|c|c|c|}
\hline STAGE & $\begin{array}{c}\text { RAPERDA FROM } \\
\text { EXECUTIVE / BUPATI }\end{array}$ & $\begin{array}{c}\text { RAPERDA FROM } \\
\text { LEGISLATIVE / DPRD } \\
\text { INITIATIVES }\end{array}$ & DISCUSSION \\
\hline $\begin{array}{c}\text { I. } \\
\text { Vertical and horizontal } \\
\text { communication }\end{array}$ & $\begin{array}{l}\text { Explanation of the Regent } \\
\text { regarding the Regional } \\
\text { Regulation }\end{array}$ & $\begin{array}{l}\text { Explanation of the } \\
\text { Commission / Joint } \\
\text { Commission / Special } \\
\text { Committee on Regional } \\
\text { Regulation }\end{array}$ & $\begin{array}{l}\text { Paripurna } \\
\text { Metting }\end{array}$ \\
\hline $\begin{array}{c}\text { II. } \\
\text { Vertical and horizontal } \\
\text { communication }\end{array}$ & $\begin{array}{l}\text { A general view of the } \\
\text { members of the DPRD } \\
\text { through the faction } \\
\text { against the Raperda } \\
\text { from Bupati. } \\
>\text { The Bupati response to } \\
\text { the general view of the } \\
\text { DPRD members }\end{array}$ & $\begin{array}{l}\text { The Bupati response } \\
\text { to the Raperda from } \\
\text { the DPRD. } \\
\text { Answer by the } \\
\text { Commission / joint } \\
\text { Commission / } \\
\text { Special Committee } \\
\text { of the DPRD to the } \\
\text { Bupati response }\end{array}$ & $\begin{array}{l}\text { Paripurna } \\
\text { Metting }\end{array}$ \\
\hline $\begin{array}{l}\text { III. } \\
\text { Vertical and horizontal } \\
\text { communication }\end{array}$ & \multicolumn{2}{|c|}{$\begin{array}{l}\text { Discussion of the Raperda in the commission / Joint } \\
\text { Commission / Special Committee with the Bupati. } \\
\text { Discussion of Raperda in the DPRD (commission / } \\
\text { joint Commission / special Committee) }\end{array}$} & $\begin{array}{l}\text { Commission } \\
\text { Meeting } \\
\text { Commission Joint } \\
\text { Meeting } \\
\text { Special } \\
\text { Committee } \\
\text { Meeting }\end{array}$ \\
\hline $\begin{array}{c}\text { IV. } \\
\text { Vertical } \\
\text { communication }\end{array}$ & \multicolumn{2}{|l|}{$\begin{array}{l}>\text { Report on the final results of } \\
>\text { Final opinion of each faction } \\
>\text { Decision-making } \\
>\text { Regent's Speech }\end{array}$} & $\begin{array}{l}\text { Paripurna } \\
\text { Metting }\end{array}$ \\
\hline
\end{tabular}

\section{Processed from the results of the interview}

In table 2 above it is explained that if at the final meeting in the DPRD has been completed and approved by the DPRD, then the Raperda is then sent by the DPRD to the Bupati through the District Secretary who in this case is the Head of the District Office. The law is to get local regulation numbering and authentication. Subsequently the District Head approved and signed the Regional Regulation to be promulgated by the District Secretary.

The implementation of local democratic practices in the process of making Perda in Sidoarjo regency is carried out by providing opportunities for each party (executive and legislative) to be an initiator and open public space to capture the aspirations of the community and socialize the draft regulation to ensure input from various parties. In a more concise manner, the researcher describes the flow of the Perda process as follows: 
Figure 1. Local Regulation Making Process

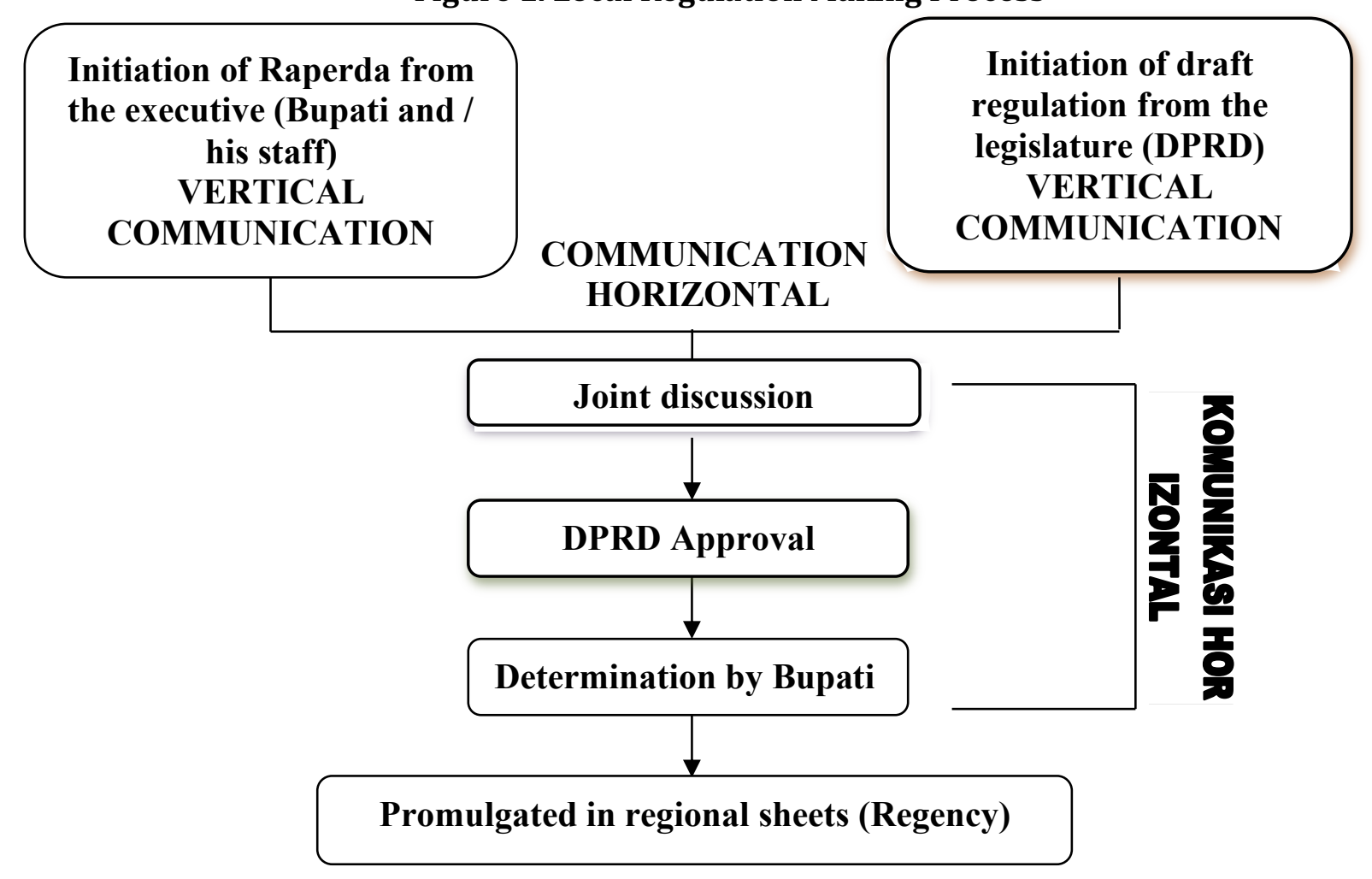

Organizational communication in the process of making local regulations can be classified by making a grouping of communication directions, namely: vertical communication and horizontal communication played by each regional government organizer.

The vertical organizational communication model for the executive is carried out by the Regent to the ranks / regional officials under him and the management of the message is carried out by the Office of Communication and Information and PPID (regional information management officer). This was also done by the legislative body where the DPRD leaders communicated to the representatives and members in the context of the deliberation of the Perda, namely at the Commission meetings, Joint Meetings, and special committee meetings / Special Committee through the Perda Formation Body.

While the horizontal communication model is carried out by the executive with the legislature in the context of the dialogue process in the sessions of discussion and determination of the Regional Regulation, especially in the plenary session.

\section{ANKWOLEGEMENT}

The research team would like to thank: Directorate of Research and Community Service Directorate General of Research and Development Strengthening Ministry of Research, Technology and Higher Education which has funded this research through contract number: 009 / SP2H / LT / K7 / KM / 2018 dated February 26, 2018.

\section{References}

Abdullah, Rozali., 2011, Implementation of Broad Autonomy with Direct Election of Regional Heads, Jakarta: Raja Grafindo Persada.

Arni Muhammad, 2002, Organizational Communication, Jakarta: Bumi Aksara.

Buduardjo,Miriam, 2008, The Basics of Political Science, 2008, Jakarta: Gramedia Pustaka Utama. 
Deden Faturohman, "Local Democracy in the Selection of Direct Regional Heads in Indonesia”, Jurnal Legality, Vol 12, Nomor 1, 2005.

Irtanto, 2008, Local Political Dynamics Era of Regional Autonomy, Yogyakarta: Pustaka Pelajar.

Ivancevich, John M., Robert Konopaske, Michael T. Matteson, 2006, Organizational Behavior and Management, Jakarta:Penerbit Erlangga.

Marbun, BN., 2004, DPRD and Regional Autonomy After the 1945 Constitution Amendment and the 2004 Regional Autonomy Law, Jakarta: Surya Multi Grafika.

R.Wayne Pace \& Don F Faules, 2006, Organizational Communication Strategies to Improve Company Performance,Bandung: Remaja Rosdakarya.

Robbins, Stephen P., 1999, the fifth edition of organizational behavior principles, Jakarta:Penerbit Erlangga.

Sadu Wasistiono, 2010, Towards Balanced Decentralization, Journal of Political Science: Entering the Second Decade of Autonomy in the Evaluation and Prospect Areas, Issue 21 Yogyakarta: AIPI-Pustaka Pelajar.

Saputra, Yulius Eka Agung., 2014, Management and Organizational Behavior, Jogjakarta: Graha Ilmu.

Sugiyono, 2005, Understanding Qualitative Research Equipped with Sample Proposals and Research Reports, Bandung : Alfabeta.

Law No. 32 of 2004 concerning Regional Government, Jakarta: Raja Grafindo Persada.

Act No.1 of 2015, concerning the Establishment of Government Regulation in Lieu of Law No.1 of 2014 concerning the Election of Governors, Bupati and Walikota. 